\title{
PENGEMBANGAN SISTEM INFORMASI IDENTIFIKASI KEBUTUHAN DAN MASALAH SISWA DALAM LAYANAN BIMBINGAN KONSELING BERBASIS WEB DI MA MUHAMMADIYAH KUDUS
}

\author{
Mohammad Shofiuddin ${ }^{1}$, Agus Suryanto ${ }^{2}$ \\ Jurusan Teknik Elektro, Universitas Negeri Semarang \\ Semarang, Indonesia \\ Email: muhsoft@gmail.com¹, agusku2@mail.unnes.ac.id ${ }^{2}$
}

\begin{abstract}
Abstrak
Pelaksanaan program BK di sekolah terutama di MA Muhammadiyah Kudus masih menggunakan sistem yang konvensional. Dalam mengambil data guru BK masih menggunakan lembaran kertas dan membagikannya ke siswa dan kemudian mengolah jawaban. Sistem informasi identifikasi masalah dan kebutuhan siswa dibuat untuk mempermudah guru BK dalam melaksanakan tugas guru BK. Metode penelitian yang digunakan adalah Research and Development (R\&D). Metode Pengembangan aplikasi menggunakan metode waterfall. Tahap pengujian diakukan untuk mengetahui kelayakan sistem. Pengujian dilakukan dengan uji blackbox dan uji pengguna. Sistem memiliki tiga hak akses yang terdiri dari admin, guru BK dan siswa. Hasil uji kelayakan dari pengguna mendapatkan $79,7 \%$ yang merupakan kategori baik yang terdiri atas uji dari guru BK mendapatkan $79,7 \%$ yang merupakan kategori baik dan dari uji siswa mendapatkan hasil $77,75 \%$ yang merupakan kategori baik.
\end{abstract}

Kata kunci: sistem informasi, bimbingan konseling, waterfall,

\begin{abstract}
The implementation of the counseling program in schools, especially in the MA Muhammadiyah Kudus, still uses a conventional system. The method of data taking the BK teacher still uses sheet of papers and distributes them to students and then processes the answers. Problem identification information systems and student needs are made to facilitate BK teachers in carrying out the duties of BK teachers. The research method used is Research and Development (R \& D). Application development method uses the waterfall method. The testing phase is carried out to determine the feasibility of the system. System testing is done by blackbox test and users test. The system has three access rights consisting of admin, counseling teacher and students. The results of the feasibility test of users get $79.7 \%$ which is a good category consisting of the test of the counseling teacher gets $79.7 \%$ which is a good category and from the test students get $77.75 \%$ which is a good category.
\end{abstract}

Keywords: information system, counseling guidance, waterfall

\section{PENDAHULUAN}

Salah satu fungsi bimbingan dan konseling adalah pengembangan diri. Pengembangan diri merupakan layanan dalam bimbingan dan konseling untuk mengembangkan seluruh potensi dan kekuatan yang dimiliki peserta didik. [3]. Mengetahui kemungkinan-kemungkinan masalah siswa, salah satu cara yang bisa digunakan oleh guru BK adalah dengan melaksanakan kegiatan aplikasi instrumentasi. Makna aplikasi instrumentasi dalam bimbingan dan konseling diartikan sebagai upaya pengungkapan yang dilakukan oleh guru BK melalui pengukuran yang dilakukan dengan menggunakan alat ukur atau instrumen tertentu. Alat ukur aplikasi instrumentasi yang merupakan salah satu kegiatan pendukung dalam BK membuat guru BK dapat menyusun program BK dengan mudah, efektif, dan efisien. 
Berkaitan dengan penyusunan program BK di sekolah, salah satu aplikasi instrumentasi non tes yang bisa digunakan ialah IKMS. IKMS (Identifikasi Kebutuhan dan Masalah Siswa) adalah sebuah alat yang digunakan untuk mengidentifikasi masalah-masalah yang mengganggu siswa berkaitan dengan tugas perkembangan peserta didik tingkat Sekolah Menengah Atas (SMA) yang berhubungan dengan masalah-masalah pribadi, sosial, belajar dan karier.

IKMS merupakan sebuah teknik yang digunakan untuk mengungkap apa saja kebutuhan dan masalah siswa. Aplikasi IKMS yang ada saat ini adalah Aplikasi IKMS SMA V 3.7 yang berupa program berformat Micrsoft Excel. Dalam penggunaannya guru $\mathrm{BK}$ harus membagikan lembar soal dan lembar jawab kepada siswa, kemudian siswa menjawab pertanyaan dari lembar yang dibagikan. Hasil dari jawaban siswa akan diolah menggunakan aplikasi IKMS yang dimasukkan secara manual oleh guru BK. Barulah hasil dari kebutuhan siswa akan diketahui.

Aplikasi IKMS yang ada saat ini masih terdapat permasalahan yaitu guru BK masih menggunakan sistem soal dengan membagikan soal dan lembar jawab kepada siswa. Selain itu, guru BK masih harus memasukkan jawaban siswa satu per satu ke aplikasi IKMS. Sistem harus dapat berinteraksi dengan siswa, yaitu siswa dapat mengisi jawaban langsung dan masuk ke sistem. Sistem bisa langsung mendapatkan jawaban dan langsung dari siswa, dan selanjutnya sistem dapat melakukan analisis terhadap jawaban tersebut. Untuk itu dibangun Sistem Informasi Identifikasi Masalah Siswa dalam Layanan Bimbingan dan Konseling.

Penelitian [2] yang bertujuan menghasilkan model layanan informasi karier untuk meningkatkan kematangan karier siswa. Hasil penelitian menunjukkan bahwa model layanan informasi karier dengan bantuan multimedia efektif meningkatkan kematangan karier siswa. Hasil pengolahan data menunjukkan bahwa semua indikator kematangan karier memperoleh nilai signifikansi jadi hasil dari penelitian menunjukkan karier siswa sebelum dan sesudah intervensi terdapat perbedaan atau mengalami peningkatan.

Penelitian [1] yang diperoleh adalah guru BK dalam melakukan pemenuhan kebutuhan alat instrumen yang digunakan tidak hanya satu atau dua saja melainkan menggunakan instrumen yang lebih banyak agar kebutuhan siswa dapat terpenuhi. Selain itu juga, guru BK harus bisa melakukan interprestasi data yang baik. Hal lain yang mendukung dalam penyusunan program adalah penetapan skala prioritas, penetapan tujuan serta prosedur penyusunan program harus bisa dilakukan secara efektif karena program yang berkualitas adalah program yang dapat melewati ke lima tahap tersebut.

Berdasarkan hasil penelitian [11] dalam menentukan kriteria data melihat prosedur aplikasi software yang digunakan. Untuk mengetahui keberhasilan guru BK menggunakan penilaian proses dan penilaian hasil. Kemudian, penentuan prioritas ditentukan atas masalah dan kebutuhan siswa. Guru BK di SMA Negeri Kabupaten Pemalang lebih memprioritaskan pada masalah siswa yang sangat mendesak untuk didahulukan. Untuk mengetahui tujuan yang ingin dicapai maka guru BK melakukan perumusan tujuan yang dimusyawarahkan dengan koordinator dan guru BK lainnya.

Penelitian [16] menyatakan aplikasi sistem informasi berbasis web digunakan untuk mengelola bagian akademik dalam penyajian laporan nilai dan keaktifan siswa secara cepat dan tepat dibandingkan secara manual. Sistem informasi berbasis web dibuat bersifat intern, artinya pengguna program ini terbatas kalangan tertentu yang memiliki hak akses terhadap sistem ini yaitu administrator dan mahasiswa.

Pada penelitian [3] aplikasi dibuat dengan berbasis website. Penelitian yang dibuat ditujukan untuk menyempurnakan kekurangan dari aplikasi Sistem Informasi Analisis Perkembangan Siswa yang berbasis desktop di mana masih ada kekurangan dalam hal pengolahan data yang dihasilkan tidak secara langsung 
karena melalui proses input manual. Aplikasi Sistem Informasi Analisis Tugas Perkembangan versi desktop juga memerlukan pembagian soal kepada siswa satu per satu yang kemudian hasilnya juga dimasukkan satu per satu.

\section{METODE}

Metode penelitian yang digunakan dalam penelitian ini adalah metode waterfall. Metode waterfall yaitu pengerjaan sistem yang dilakukan dengan berurutan atau linear.

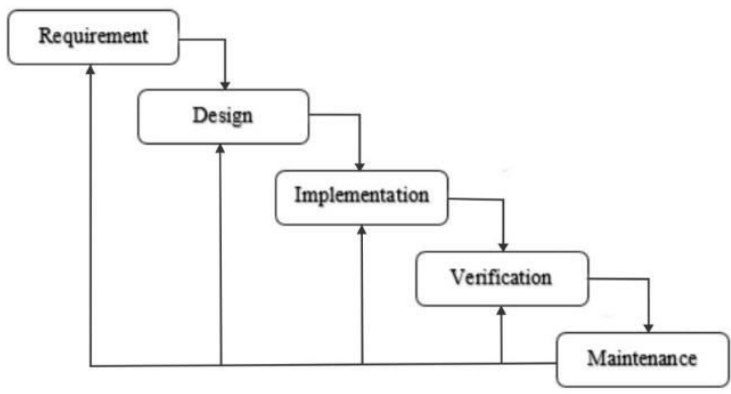

Gambar 1 Metode Waterfall

Analisis Sistem

Tahap analisis membahas mengenai analisis kebutuhan sistem, analisis kebutuhan perangkat keras dan perangkat lunak sistem dan analisis kebutuhan pengguna. Langkah pertama adalah analisis kebutuhan. Pada tahap ini peneliti melakukan wawancara langsung dengan guru BK di MA Muhammadiyah Kudus sehingga peneliti dapat mengidentifikasi permasalahan yang perlu diselesaikan.

Tabel 1 Tabel Permasalahan Sekolah

\begin{tabular}{|c|c|c|}
\hline No & Identifikasi Masalah & $\begin{array}{l}\text { Kebutuhan } \\
\text { Pengguna }\end{array}$ \\
\hline 1. & $\begin{array}{l}\text { Program BK di MA } \\
\text { Muhammadiyah } \\
\text { Kudus masih } \\
\text { menggunakan } \\
\text { lembar soal kepada } \\
\text { siswa dalam } \\
\text { pengambilan data. } \\
\text { Proses ini } \\
\text { memakan waktu } \\
\text { dengan pembagian } \\
\text { soal kepada siswa } \\
\text { dan kurang efisien }\end{array}$ & $\begin{array}{l}\text { MA } \\
\text { Muhammadiyah } \\
\text { Kudus } \\
\text { membutuhkan } \\
\text { sistem } \\
\text { informasi untuk } \\
\text { mendapatkan } \\
\text { data secara } \\
\text { cepat dan } \\
\text { efisien. }\end{array}$ \\
\hline
\end{tabular}

\begin{tabular}{|l|l|l|}
\hline & $\begin{array}{l}\text { karena guru BK } \\
\text { harus mengambil } \\
\text { kembali lembar soal } \\
\text { dari siswa }\end{array}$ & \\
\hline 2. & $\begin{array}{l}\text { Guru BK } \\
\text { menghitung satu } \\
\text { persatu jawaban } \\
\text { dari siswa. Hal ini } \\
\text { membutuhkan } \\
\text { waktu yang lama. }\end{array}$ & $\begin{array}{l}\text { Sekolah } \\
\text { memerlukan } \\
\text { sistem yang } \\
\text { dapat } \\
\text { menghitung } \\
\text { jawaban dari } \\
\text { siswa dan } \\
\text { ditampilkan } \\
\text { secara } \\
\text { langsung }\end{array}$ \\
\hline
\end{tabular}

1. Analisis Kebutuhan Perangkat Keras

Dalam penelitian ini, perangkat keras yang digunakan yaitu sebuah laptop dengan spesifikasi sebagai berikut:

a. Processor: AMD E1-2100 APU DualCore Processor @1.0Ghz

b. RAM : $4 \mathrm{~GB}$

c. Drive : 500 GB HDD

Analisis Kebutuhan Perangkat Lunak

Dalam penelitian ini, perangkat lunak yang digunakan sebagai berikut:

a. OS: Windows 10 Education 64-bit

b. Web Browser: Microsoft Edge

c. Web Server: XAMPP

d. Script Editor : Atom

e. Scripct Engine : PHP

2. Analisa user

Sistem informasi IKMS dibuat untuk 3 user yaitu :

1. Admin : admin mengelola pengguna sistem informasi. Tugas admin yaitu menambah, edit, dan hapus pengguna sistem.

2. Guru BK : guru BK mengatur sebaran kelas siswa dan dapat melihat hasil dari perhitungan jawaban seluruh siswa.

3. Siswa : siswa bertugas menjawab soal yang ada di sistem. Siswa dapat melihat hasil dari jawaban siswa itu sendiri berupa tabel dan persentase.

Desain

Proses desain yaitu menerjemahkan syarat atau kebutuhan ke dalam sebuah representasi perangkat lunak agar dapat diperkirakan suatu kualitas sebelum dimulai pemunculan kode. Desain UML (Unified Modelling Language) 
UML adalah sebuah bahasa yang menggunakan grafik atau gambar untuk memvisualisasi, menspesifikasikan, membangun, dan mendokumentasikan dari sebuah sistem pengembangan software berbasis object-oriented. Tahap ini menjelaskan tentang dua model diagram pada UML dari aplikasi ini yaitu Use Case Diagram dan Activity Diagram.

Desain arsitektur berisi bagan yang menggambarkan arus logika yang akan diproses di suatu awal program sampai akhir.

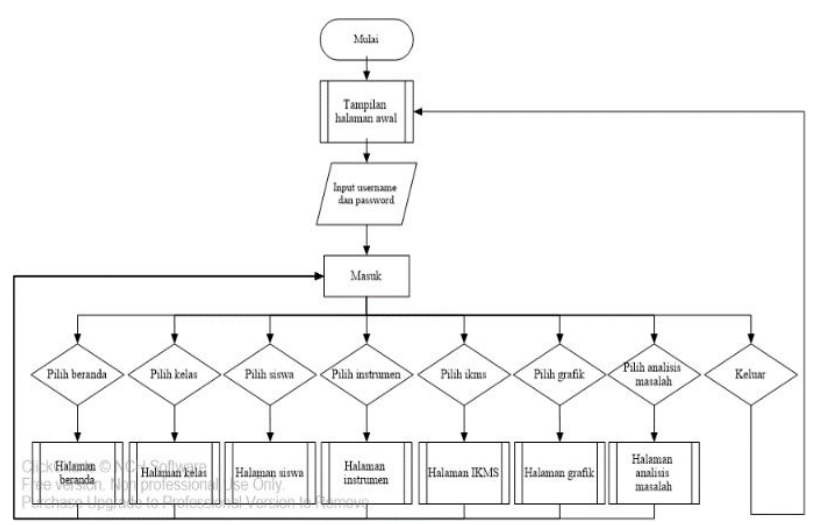

Gambar 2 Flowchart menu guru

Use Case Diagram

Use case diagram mendeskripsikan bentuk sistem dari sudut pandang pengguna, berguna untuk membantu memahami kebutuhan. Aplikasi yang dikembangkan peneliti terdapat 4 use case diagram yaitu untuk guest, admin, guru dan siswa. Perbedaannya dari pengguna yaitu fasilitas atau menu yang dapat dijalankan dari aplikasi berbeda untuk masing-masing pengguna.

Uji blackbox

Menurut [10] uji blackbox berfokus pada persyaratan fungsional perangkat lunak. Pengujian blackbox memungkinkan pembuat perangkat lunak menghasilkan kondisi input yang sepenuhnya menggunakan persyaratan fungsional untuk satu program. Pengujian blackbox berupaya menemukan kesalahan dalam fungsi-fungsi yang tidak benar atau hilang, kesalahan interface, kesalahan dalam struktur data atau akses basis data, kesalahan kinerja dan inisialisasi dan kesalahan terminasi pada sistem.
Pengujian blackbox dalam penelitian ini bertujuan untuk menguji fungsionalitas program dan dapat mengetahui kesalahan pada perangkat lunak, apabila terdapat kesalahan pada fungsional perangkat lunak, peneliti dapat segera memperbaiki sebelum proses pengujian selanjutnya

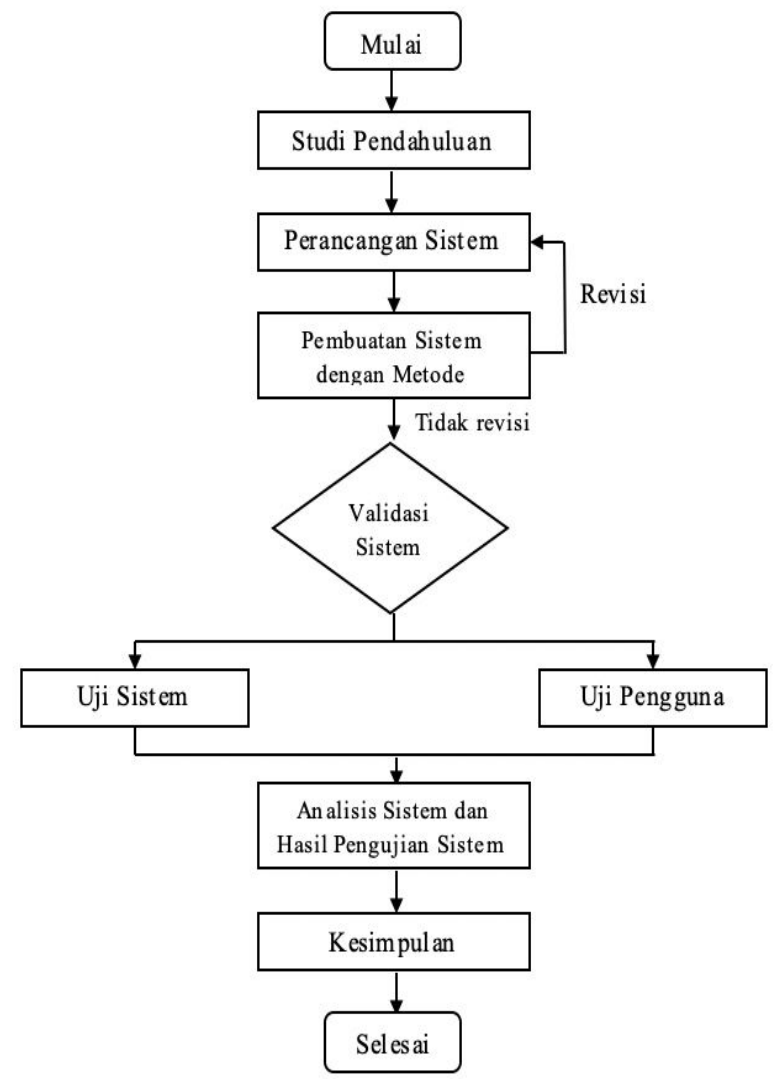

Gambar 3 Tahapan Penelitian

Parameter Penelitian

Pada penelitian ini aspek yang akan dinilai terdiri dari 3 aspek yaitu :

1. Kelayakan penilaian

Aspek yang berdasar pada faktor kelayakan perangkat lunak. [10] meliputi aspek reliabilitas, integritas, usability, maintainability, flexibility, portability.

2. Efisiensi

Penilaian efisiensi sistem dinilai dari aspek efisiensi dan juga aspek portabilitas.

3. Efektivitas

. Penilaian aspek yang meliputi kemudahan dalam pengaksesan sistem, kesesuaian tampilan dan informasi yang disajikan sistem. Penilaian efektivitas sistem dinilai dari aspek kebenaran, aspek integritas, 
aspek usabilitas, aspek maintainabilitas dan aspek flexibilitas.

Analisis Data

Setelah mendapatkan data-data dari hasil kuesioner yang dibagikan ke responden, setelah itu dilakukan analisis data untuk mengetahui kelayakan sistem berdasarkan faktor kualitas perangkat lunak. [10] Keefektifan dan efisiensi sistem dinilai dari aspek faktor kualitas perangkat lunak. [10] Prosedur penelitian analisa data adalah sebagai berikut :

1) Memeriksa kelengkapan jawaban pada kuesioner yang telah diisi responden.

2) Mengklasifikasikan jawaban setiap pertanyaan dengan memberi skor sesuai dengan bobot yang telah ditentukan sebelumnya.

3) Membuat tabulasi data.

4) Menghitung persentase dari tiap-tiap kategori dengan rumus :

Kategori Penilaian $(\%)=\frac{n}{N} \times 100 \%$

Keterangan : $\%=$ persentase kategori $\mathrm{n}=$ jumlah skor tiap indikator $\mathrm{N}=$ jumlah skor ideal

5) Berdasarkan persentase yang diperoleh kemudian ditampilkan ke dalam tabel untuk menentukan kategori "Sangat Baik", "Baik" , "Tidak Baik", "Sangat Tidak Baik", perlu menentukan nilai maksimum, nilai minimum, dan intervalnya. Dengan mengadaptasi rumus persentase, maka dapat menentukan nilai indeks minimum dan nilai indeks maksimum. Sedangkan untuk menentukan panjang interval dapat dicari dengan cara jarak (data terbesar - data terkecil) dibagi dengan jumlah kelas interval. Data interval dapat dianalisis dengan menghitung rata-rata jawaban berdasarkan skoring setiap jawaban dari responden.

\section{HASIL DAN PEMBAHASAN}

Hasil yang didapat dalam penelitian ini adalah produk sistem informasi identifikasi masalah dan kebutuhan siswa, data hasil uji black box, data hasil uji isi sistem, data hasil uji pengguna. Hasil yang diperoleh akan dipaparkan sebagai berikut: 1. Halaman Beranda
Pada halaman ini terdapat menu navigasi yaitu Beranda dan Masuk.

\section{IKMS}

IKMS

Gambar 4 Tampilan halaman beranda

2. Halaman Masuk

Halaman ini digunakan untuk masuk ke dalam sistem oleh pengguna umum ataupun admin.

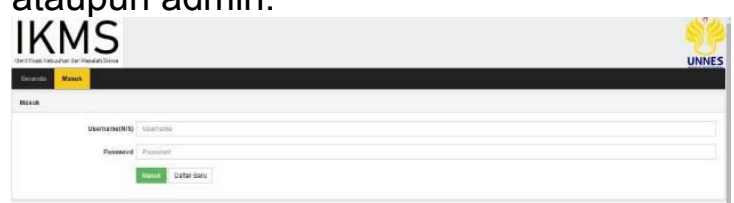

Gambar 5 Tampilan Halaman Login

3. Kelola pengguna

Pada halaman ini ditampikan semua pengguna dan terdapat menu untuk mengelola pengguna.

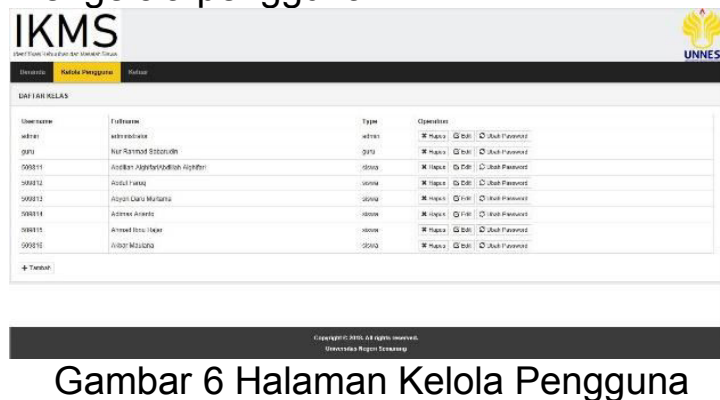

4. Kelas

Pada halaman ini, ditampilkan semua daftar kelas yang ada pada sistem.

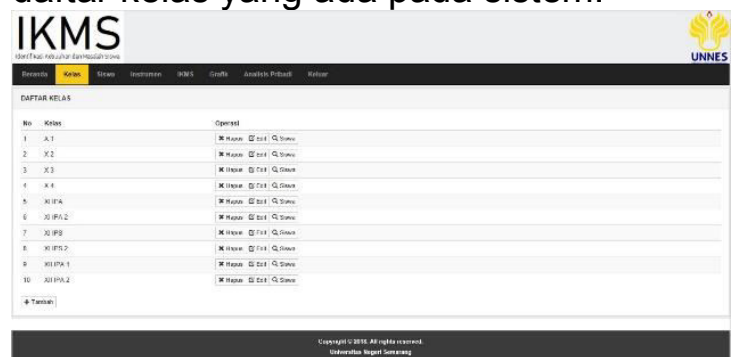

Gambar 7 Tampilan halaman kelas

5. Menu instrumen siswa 
Halaman ini menampilkan kategori bidang instrumen.

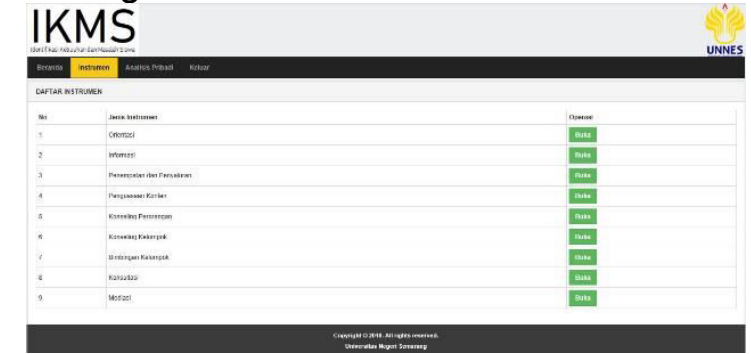

Gambar 8 Tampilan kategori instrumen IKMS

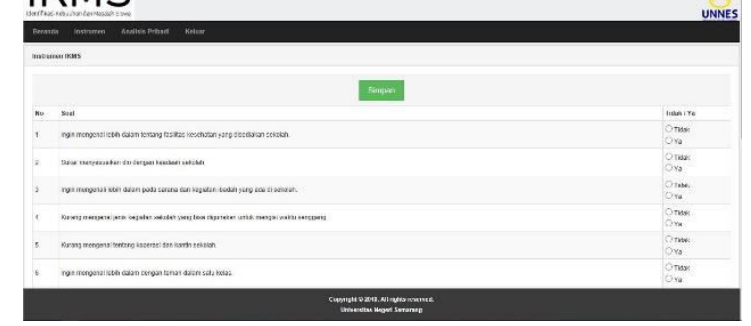

Gambar 9 Tampilan isi instrumen

sesuai dengan kategori bidang.

Hasil Pengujian

Pengujian yang dilakukan pada sistem informasi identifikasi kebutuhan dan masalah siswa dibangun bertujuan untuk membuktikan bahwa aplikasi ini sudah berjalan sesuai dengan tahap perancangan sistem. Pada penelitian ini pengujian dilakukan dari aspek functionality dan aspek usability.

Pengujian

merupakan

aspek

functionality pengujian terhadap kemampuan perangkat lunak dalam menyediakan fungsi sesuai kebutuhan pengguna apabila digunakan dalam kondisi tertentu. Pengujian aspek functionality dilakukan menggunakan pengujian blackbox. Pengujian blackbox bertuju pada persyaratan fungsional perangkat lunak. Dengan demikian, pengujian blackbox memungkinkan perekayasa perangkat lunak mendapatkan serangkaian kondisi masukan yang menggunakan semua persyaratan fungsional untuk suatu program. Pengujian blackbox bukan merupakan satu alternatif dari teknik whitebox, tetapi merupakan pendekatan komplementer yang kemungkinan besar mampu mengungkap kelas kesalahan daripada metode whitebox [10]
Pengujian blackbox berusaha menemukan kesalahan dalam kategori sebagai berikut :

1. Fungsi-fungsi yang tidak benar atau hilang

2. Kesalahan interface

3. Kesalahan dalam struktur data atau akses database eksternal

4. Kesalahan kinerja

Pengujian aspek usability adalah pengujian terhadap kemampuan perangkat lunak untuk dapat dipahami, dipelajari, digunakan dan menarik bagi pengguna ketika digunakan dalam kondisi tertentu. Pengujian usability pada penelitian ini menggunakan faktor kualitas perangkat lunak [10] yang terdiri dari aspek kebenaran, reliabilitas, efisiensi, integritas, usabilitas, maintainabilitas, flexibilitas, portabilitas. Pengujian aspek usability dilakukan kepada beberapa responden untuk mengetahui apakah aplikasi ini layak untuk digunakan sebagai sistem informasi identifikasi masalah dan kebutuhan siswa di sekolah. Hasil dari pengujian aspek usability menggunakan angket validasi sistem uji, isi sistem, dan uji pengguna. Uji isi sistem dilakukan kepada pihak yang berkaitan dengan sekolah untuk mengetahui kesesuaian informasi yang disajikan sistem dengan kebutuhan sistem, untuk mengetahui efektivitas sistem dan efisiensi sistem. Uji pengguna dilakukan kepada siswa sekolah untuk mengetahui keefektifan dan efisiensi sistem.

Hasil Uji Black Box

Uji black box digunakan untuk uji fungsional dari tombol, fungsional text field serta peringatan yang muncul. Hasil dari uji blackbox yang telah dilakukan bertujuan untuk mengecek berjalan atau tidaknya suatu fungsi pada sistem agar sistem yang dibuat berfungsi dan tidak memiliki kendala dalam pengoperasian. Aspek yang diuji dalam pengujian black box meliputi aspek pengujian menu login, pengujian menu kelola pengguna, pengujian menu kelas, pengujian menu siswa, pengujian menu ikms, pengujian menu analisis masalah, pengujian menu instrumen, dan pengujian menu logout. Rekap hasil uji black box 
sistem informasi simpan pinjam dapat dilihat pada lampiran 5 .

Berdasarkan hasil pengujian black box, mendapatkan hasil bahwa pengujian aspek functionality dari sistem informasi identifikasi kebutuhan dan masalah siswa berhasil $100 \%$. Artinya fungsionalitas dan proses yang terdapat pada sistem telah berjalan dengan baik sesuai dengan perancangan sistem yang telah dibuat.

Hasil Uji Isi Sistem

Uji isi sistem dilakukan untuk mengetahui kesesuaian informasi dengan kebutuhan sekolah, keefektifan sistem, dan efisiensi sistem. Uji isi sistem dilakukan kepada 1 responden dari guru sekolah MA Muhammadiyah Kudus pada tanggal 6 Juni 2018. Uji isi Sistem dilakukan dengan mendemokan sistem kepada responden, responden kemudian memeriksa ,mencoba sistem dan menilai sistem secara keseluruhan dengan mengisi angket. Rekap hasil uji isi sistem dapat dilihat pada tabel 2.

Tabel 2 Hasil Uji isi sistem

\begin{tabular}{|c|c|c|c|c|c|c|c|c|c|c|}
\hline \multirow{3}{*}{$\begin{array}{l}\text { Respon } \\
\text { den }\end{array}$} & \multicolumn{10}{|c|}{ Aspek yang dinilai } \\
\hline & \multicolumn{2}{|c|}{$\begin{array}{c}\text { Kebena } \\
\text { ran }\end{array}$} & \multicolumn{3}{|c|}{$\begin{array}{l}\text { Efisien } \\
\text { si }\end{array}$} & \multicolumn{4}{|c|}{ Usabilitas } & \multirow{2}{*}{$\begin{array}{c}\text { Port } \\
a b \\
\text { ilita } \\
\text { s } \\
10\end{array}$} \\
\hline & 1 & 2 & 3 & 4 & 5 & 6 & 7 & 8 & 9 & \\
\hline $\begin{array}{l}\text { Respon } \\
\text { den } 1\end{array}$ & 3 & 4 & 3 & 3 & 3 & 3 & 4 & 3 & 3 & 3 \\
\hline $\begin{array}{l}\text { Jumlah } \\
\text { Persent } \\
\text { ase }\end{array}$ & \multicolumn{2}{|c|}{$87,5 \%$} & \multicolumn{3}{|c|}{$75 \%$} & \multicolumn{4}{|c|}{$81,25 \%$} & $\begin{array}{l}75 \\
\%\end{array}$ \\
\hline $\begin{array}{l}\text { Rata- } \\
\text { rata } \\
\text { persent } \\
\text { ase }\end{array}$ & \multicolumn{10}{|c|}{$79,7 \%$} \\
\hline
\end{tabular}

Dari hasil uji isi sistem dapat diperoleh hasil sebagai berikut :

Persentase kelayakan sistem dari aspek reliabilitas, aspek, aspek efisiensi, aspek usabilitas dan aspek portabilitas.

Dari hasil uji validasi sistem diperoleh persentase aspek reliabilitas sebesar $87,5 \%$ dengan kategori sangat baik, persentase aspek efisiensi sebesar $75 \%$ dengan kategori baik, persentase aspek usabiitas sebesar $81,25 \%$ dengan kategori sangat baik, persentase aspek portabilitas sebesar $75 \%$ dengan kategori baik. Dari keempat persentase tersebut diperoleh rata-rata persentase sebesar $\mathbf{7 9 , 7 \%}$ untuk kelayakan sistem dengan kategori baik. Artinya sistem yang dibangun sangat layak untuk digunakan.

Tabel 3 Hasil Uji

\begin{tabular}{|c|c|c|c|c|c|c|c|c|c|c|}
\hline \multirow{3}{*}{$\begin{array}{l}\text { Respo } \\
\text { nden }\end{array}$} & \multicolumn{10}{|c|}{ Aspek yang dinilai } \\
\hline & \multicolumn{2}{|c|}{$\begin{array}{l}\text { Kebena } \\
\text { ran }\end{array}$} & \multicolumn{3}{|c|}{$\begin{array}{l}\text { Efisien } \\
\text { si }\end{array}$} & \multicolumn{4}{|c|}{$\begin{array}{l}\text { Usabilita } \\
\mathrm{s}\end{array}$} & $\begin{array}{l}\text { Port } \\
\text { ab } \\
\text { ilitas }\end{array}$ \\
\hline & 1 & 2 & 3 & 4 & 5 & 6 & 7 & 8 & 9 & 10 \\
\hline Res 1 & 3 & 3 & 3 & 3 & 4 & 3 & 3 & 4 & 4 & 3 \\
\hline Res 2 & 3 & 3 & 4 & 3 & 4 & 3 & 4 & 3 & 3 & 3 \\
\hline Res 3 & 3 & 3 & 3 & 3 & 4 & 3 & 3 & 4 & 3 & 3 \\
\hline Res 4 & 3 & 3 & \begin{tabular}{l|l}
4 \\
\end{tabular} & 3 & 3 & 4 & 3 & 4 & 3 & 3 \\
\hline Res 5 & 3 & 3 & 4 & 3 & 3 & 4 & 4 & 3 & 4 & 3 \\
\hline Res 6 & 3 & 3 & 4 & \begin{tabular}{l|l}
4 & \\
\end{tabular} & 3 & 3 & 4 & 3 & 3 & 3 \\
\hline $\begin{array}{l}\text { Jumlah } \\
\text { Persen } \\
\text { tase }\end{array}$ & \multicolumn{2}{|c|}{$75 \%$} & \multicolumn{3}{|c|}{$86 \%$} & \multicolumn{4}{|c|}{$85,4 \%$} & $\begin{array}{l}75 \\
\%\end{array}$ \\
\hline $\begin{array}{l}\text { Rata- } \\
\text { rata } \\
\text { persen } \\
\text { tase }\end{array}$ & \multicolumn{10}{|c|}{$80,35 \%$} \\
\hline
\end{tabular}

Hasil Uji Isi Pengguna

Uji isi pengguna dilakukan untuk mengetahui kesesuaian informasi dengan kebutuhan koperasi, keefektifan sistem, dan efisiensi sistem. Uji isi sistem dilakukan kepada 6 responden dari siswa siswi MA Muhammadiyah Kudus pada 6-7 Juni 2018 . Uji isi Sistem dilakukan dengan mendemokan sistem kepada responden, responden kemudian memeriksa ,mencoba sistem dan menilai sistem secara keseluruhan dengan mengisi angket. Rekap hasil uji isi sistem dapat dilihat pada tabel 3.

Persentase kelayakan sistem dari aspek reliabilitas, aspek, aspek efisiensi, aspek usabilitas dan aspek portabilitas.

Dari hasil uji validasi sistem diperoleh persentase aspek reliabilitas sebesar $75 \%$ dengan kategori baik, persentase aspek efisiensi sebesar $86 \%$ dengan kategori sangat baik, persentase aspek usabiitas sebesar $85,4 \%$ dengan kategori sangat baik, persentase aspek portabilitas sebesar $75 \%$ dengan kategori baik. Dari keempat persentase tersebut diperoleh rata-rata persentase sebesar $\mathbf{8 0 , 3 5 \%}$ untuk 
kelayakan sistem dengan kategori baik. Artinya sistem yang dibangun sangat layak untuk digunakan.

Pembahasan

Sistem informasi identifikasi masalah dan kebutuhan siswa adalah sistem berbasis web yang dibangun dengan tujuan untuk memudahkan guru BK dalam mengumpulkan informasi siswa yang masih konvensional yaitu dengan memberikan lembaran instrumen ke siswa dan membagikan satu persatu kepada siswa, meningkatkan efisiensi waktu pada proses penghitungan jawaban dan menampikan jawaban secara langsung.

Pada penelitian [1] dan [11] Aplikasi yang digunakan yaitu berupa Microsoft Excel sehingga pengguna masih harus memasukkan jawaban satu per satu ke dalam aplikasi. Aplikasi yang dibangun peneliti memiliki fitur mengisi instrumen di dalam aplikasi. Jadi, siswa hanya perlu membuka aplikasi dan langsung menjawab di dalam aplikasi dan jawaban langsung masuk dan diproses oleh sistem.

Penelitian oleh [3] menggunakan cara yang sama yaitu mengembangkan aplikasi yang sudah ada. Perbedaan aplikasi peneliti terletak perbedaan pengumpulan data yaitu ada di instrumen, pengolahan instrumen dan hasil pengolahan instrumen. Tujuan peneliti yaitu menyempurnakan aplikasi Identifikasi Masalah dan Kebutuhan Siswa di sekolah yang masih berbasis desktop.

Hasil dari pengujian functionality dengan pengujian blackbox yang berfokus pada pengecekan fungsi tombol dan menu sistem. Hasil dari pengujian fungsionalitas pada sistem mendapatkan hasil $100 \%$ yang sesuai. Hal ini dapat disimpulkan bahwa fungsi-fungsi yang ada dalam sistem dapat berfungsi sebagaimana semestinya.

Uji isi sistem dilakukan untuk mengetahui kesesuaian isi sistem dengan kebutuhan seklah, untuk mengetahui keefektifan sistem yang dinilai dari asek kebenaran dan aspek usabilitas. Untuk mengetahui efisiensi sistem yang dinilai dari aspek efisiensi dan aspek portabilitias. Uji isi sistem dilakukan kepada 1 responden dengan hasil meningkatkan keefektifan sistem IKMS dengan hasil uji keefektifan sistem sebesar $79,7 \%$ termasuk kategori baik. Sistem IKMS berbasis web sangat meningkatkan efisiensi dalam mengolah instrumen kebutuhan siswa.

Uji pengguna dilakukan untuk mengetahui keefektifan sistem yang dinilai dari aspek kebenaran, aspek usabilitas. Untuk mengetahui efisiensi sistem dinilai dari aspek efisiensi dan aspek portabilitas. Uji pengguna melibatkan 6 responden dengan hasil Sistem Informasi IKMS berbasis web sangat memudahkan pengguna. Hal ini ditunjukkan dengan hasil efektivitas sistem dari hasil uji pengguna sebesar $\mathbf{8 0 , 3 \%}$ termasuk kategori baik.

Berdasarkan hasil uji isi sistem dan uji pengguna dapat disimpulkan Sistem Informasi IKMS berbasis web layak untuk digunakan dengan hasil pengujian sebesar $80 \%$ termasuk kategori baik. Sistem Informasi IKMS berbasis web sangat meningkatkan keefektifan dalam pengolahan jawaban instrumen dengan hasil rata-rata pengujian sebesar $82,3 \%$ termasuk kategori sangat baik. Sistem Informasi IKMS berbasis web sangat meningkatkan efisiensi dalam mengumpulkan jawaban instrumen dengan hasil rata-rata pengujian sebesar $\mathbf{7 7 , 7 5 \%}$ termasuk kategori baik.

\section{SIMPULAN}

\section{Simpulan}

1. Sistem Informasi IKMS Berbasis Web pada MA Muhammadiyah Kudus layak untuk digunakan untuk membantu proses pengumpulan dan penghitungan di Sekolah, berdasarkan hasil uji kelayakan sistem sebesar $79,7 \%$ termasuk kategori baik.

2. Sistem Informasi IKMS Berbasis Web pada MA Muhammadiyah Kudus meningkatkan keefektifan dalam pengolahan instrumen, berdasarkan hasil uji efektivitas sistem sebesar $79,7 \%$ termasuk kategori baik.

3. Sistem Informasi IKMS Berbasis Web pada MA Muhammadiyah Kudus sangat meningkatkan efisiensi dalam menjawab instrumen BK di sekolah, berdasarkan 
hasil uji efisiensi sistem sebesar $77,75 \%$ termasuk kategori baik.

\section{Saran}

1. Untuk meningkatkan keefektifan dan efisiensi dari penggunaan layanan IKMS secara konvensional, Sistem Informasi IKMS Berbasis Web layak untuk digunakan pada MA Muhammadiyah Kudus

2. Perlu adanya pengembangan sistem lebih lanjut yang menitik beratkan pada sistem keamanan sistem.

3. Perlu adanya pengembangan fitur sistem untuk proses ekspor data ke dalam bentuk file yang bisa diolah di aplikasi desktop seperti word, excel dan atau pdf.

\section{REFERENSI}

[1] Anni, C. T. 2013. Pengembangan Model Penyusunan Program BK Bidang Bimbingan Belajar Berbantuan Sistem Informasi Manajemen di SMA Negeri Kota Semarang. Skripsi. Universitas Negeri Semarang. Semarang.

[2] Athiyah, I. I. Tadjri dan E. Purwanto. 2014. Career Information Service Model Multimedia-Assisted For Increasing Students Career Maturity. Jurnal Bimbingan Konseling: 3

[3] Aulia, E. 2016. Pengembangan Sistem Informasi Analisis Perkembangan Siswa dalam Layanan Bimbingan dan Konseling di SLTA. Skripsi. Universitas Negeri Semarang. Semarang.

[4] Janner, S. 2010. Rekayasa Perangkat Lunak. Yogyakarta: Andi

[5] Jogiyanto. 2005. Sistem Teknologi Informasi. Edisi II. Yogyakarta: Andi Offset.

[6] Kadir. A. 2014. Pengenalan Sistem Informasi Edisi Revisi. Yogyakarta: Andi.
[7] Kustiyahningsih, Y dan D. R. Anamisa. 2011. Pemrograman Basis Data. Berbasis Web Menggunakan PHP \& MySql. Yogyakarta: Graha IImu.

[8] Nugroho. B. 2008. Aplikasi Pemograman Web Dinamis dengan PHP dan MYSQL. Yogyakarta: Gava media.

[9] Peraturan Menteri Pendidikan dan Kebudayaan Republik Indonesia Nomor 111 Tahun 2014. Bimbingan Konseling pada Pendidikan Dasar dan Menegah. 14 Oktober 2014. Berita Negara Republik Indonesia Tahun 2014 Nomor 1544.Jakarta.

[10] Pressman. R. S. 2010. Software Engineering A Practitioner's Approach Seventh Edition. New York :McGrawHill

[11] Prilintia, U. 2015. Studi Deskriptif Penggunaan Software Identifikasi Kebutuhan dan Masalah Siswa (IKMS $尺$ ) dalam Perencanaan Program Bimbingan dan Konseling Di SMA Negeri Kabupaten Pemalang Tahun 2014/2015. Skripsi. Universitas Negeri Semarang. Semarang.

[12] Sibero. A. F.K. 2013. Web programming power pack. Yogyakarta: MediaKom.

[13] Sommerville. I. 2011. Software Engineering. Ninth Edition. Boston: Addison-Wesley.

[14] Sugiyono. 2013. Metodelogi Penelitian Kuantitatif, Kualitatif Dan R\&D. Bandung: Alfabeta.

[15] Sutarman. 2007. Membangun Aplikasi Web Dengan PHP dan MySQL. Yogyakarta: Graha ilmu.

[16] Utama, Y. 2011. Sistem Informasi berbasis Web Jurusan Sistem Informasi Fakultas IImu Komputer Universitas Sriwijaya. Jurnal Sistem Informasi 